JAN HERCIK

Masaryk University, Czech Republic

ZDENĚK SZCZYRBA

Palacký University, Czech Republic

\title{
Post-military areas as space for business opportunities and innovation
}

One of the key issues with which many - not only Czech - municipalities are confronted today is the reconversion and revitalization of abandoned buildings or complete areas which have lost their original function. The original function of these sites is quite varied, just as is their potential for subsequent revitalization. One of the types of brownfields is also the so-called military brownfield, which comes into being as a result of the departure of armed forces from the given location, and which today, along with industrial and agricultural brownfields, forms the third largest group in the Czech Rep.

Although the term 'brownfield' was practically unknown in Czech and also Central European specialized literature until recently (Kuda, Smolová 2007, p. 21), in the region of Western Europe and North America it has been generally accepted already since the 1970s onwards (Marcuse, Van Kempen 2000). The topic of sites abandoned when their previous function has been cancelled is obviously much older and follows the history of humanity itself. Whatever became of an abandoned mediaeval fort or castle, which had lost its primary defensive function? None other but former military buildings are the oldest type of brownfield. However, it does not concern only the above- mentioned castles and forts, but also entire military complexes, concentrated in a larger area, such as large fortresses or defense complexes. Even in the Czech Republic several are to be found - e.g. Olomouc, Terezín, Josefov. After their status of fortress was cancelled, or when most of the soldiers had left, representatives of all these towns had to deal with problems similar to those which afflicted municipalities are confronted with today. We can deduce from historical experiences that the departure of armed forces did not have only negative consequences for the municipalities concerned, rather on the contrary. Frequently, demilitarization of the municipality became an impulse for further development of the town (for more see e.g. Šilhánková 2006).

The process of demilitarization, which happened in several countries in the world due to the geopolitical changes brought about by the end of the Cold War and with the downfall of the Soviet Union, is, however, in many respects absolutely unique. First and foremost, 
it concerns a large number of countries, which were influenced by this process, and as a result - a number of newly emerged military brownfields. Among the most afflicted regions were the post-communist countries of Central Europe, which under the reign of Communist totalitarian regimes were significantly overmilitarized. On the one hand, there was the great strength of the national armies, on the other hand, there were more than 500 thousand Soviet soldiers deployed in these countries (state of v k 1. 1. 1990); (Pecka 1996) - most of the military units were deployed in the western halves of both republics (Jarczewski, Kurylo 2009 , p. 247). Because of this, the impacts of the process of demilitarization were also spatially considerably uneven.

\section{Demilitarization of the Czech Republic after 1989}

Demilitarization, although it is without a doubt one of the basic transformational processes (Matlovič et al. 2001, p. 91), stands somewhat aside of the interest of the scientific community; it is primarily deindustrialization that is being dealt with as the most important part of the transformational process, and this by geographers as well as by e.g. sociologists (D. Bell, A. Touraine or in the CR: J. Keller). Due to the magnitude of its impact, this interest is of course logical. In a number of its aspects, demilitarization has much in common with deindustrialization. What is, nevertheless, completely different are the driving forces behind these processes. In deindustrialization, they are mainly economic influences. One of the most significant ones is globalization (Keller 2011, p. 3), which has significantly altered the economic, but also the demographic map of the world (Fňukal 2011, p. 80). In the case of demilitarization, the influences are of a different kind - political and military-strategic.

The start of demilitarization in what was Czechoslovakia can be traced to the very beginning of the 1990s. Back then, the process was started by the significant reduction of the number of soldiers in the armed forces (the Czechoslovak as well as Soviet ones) and of the number of places of their activity. In the case of just the Soviet occupying army, it concerned more than 70 thousand soldiers, distributed in more than 80 locations throughout the whole republic (Pecka 1996). The headcount of the Czechoslovak Army was almost two hundred thousand.

In the initial phase, demilitarization was primarily connected with the transfer of the Soviet Army out of Czechoslovakia; this process was finished by the middle of 1991 . Simultaneously with the transfer, the reduction of the national armed forces was started too, which was in line with the general political changes and the drawing up of a completely new military doctrine, which no longer counted with a massive offensive army as did the original, and planned the formation of new peace armed forces, defensive in character. The end of this phase, which is often called ,democratizing“, is often placed in 1993. In the following years, the reduction of the number of soldiers and places of their deployment continued (see fig. 1). 


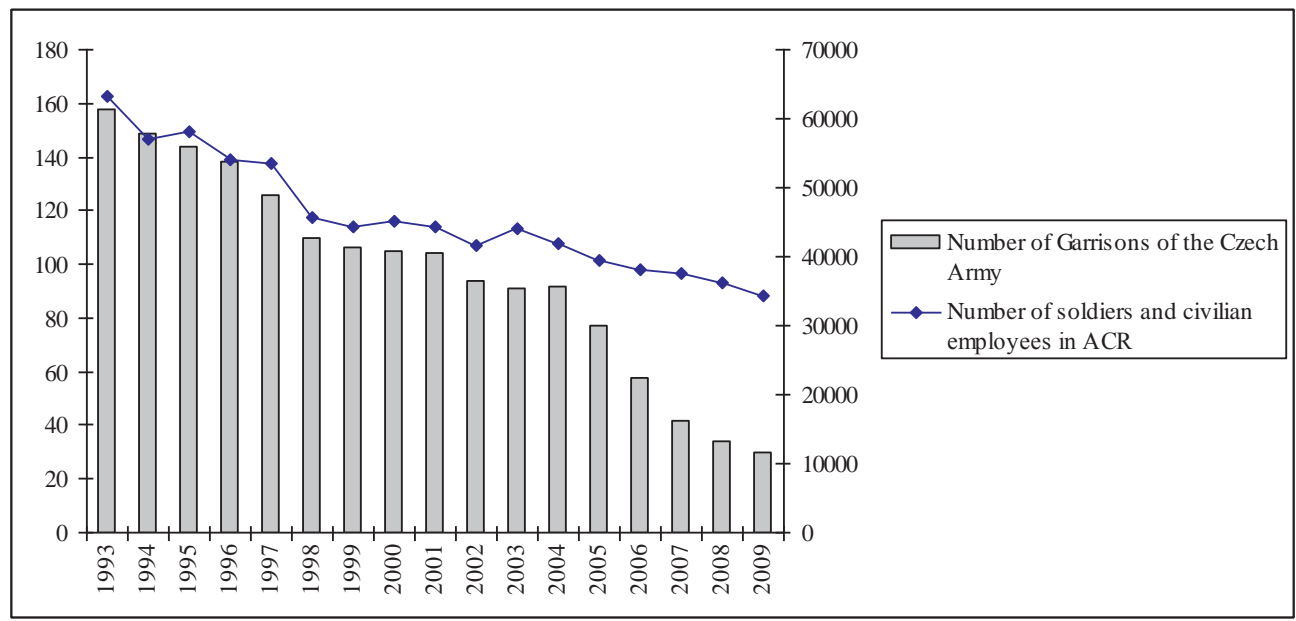

Fig. 1. Development of the number of garrisons and of the number of soldiers in the Armed Forces of the Czech Republic in the period 1993-2009

Source: Ministry of Defence of the Czech Republic and Armed Forces of the Czech Republic

\section{THE REVITALIZATION OF MILITARY BROWNFIELDS}

Military brownfields cannot be considered a homogeneous group of sites which have lost their former military function. Between individual ones fundamental differences can be seen, which substantially influence the potential of their further revitalization and future development. One of the most essential differences is the size of the buildings and sites, their original function and technical state, but also the degree of the environmental burden of the locations. These factors can be ranked among so-called internal factors, resulting directly from the original function of the brownfield. Besides these factors, an important role in the reconversion of brownfields is played by so-called external factors, one of the most fundamental of which is the factor of the position of the brownfield towards an urbanized area. As a basis, the positional classification of brownfields as worked out by the Institute for Sustainable Development can be used. The classification divides brownfields into three basic categories (Jackson 2003, p. 6). This classification, however, works only for brownfields which are located in the area within a municipality and does not take into account the large group of brownfields the position of which is located outside of municipalities on the one hand, but which, on the other hand, are a direct extension of a built-up area or lie in its direct proximity. The classification thus can be completed by a fourth category, that of brownfields outside of municipalities. As for military brownfields, the examples are very often a large, monofunctional site (airports, shooting ranges, etc.) or a large complex of barracks, consisting of surfaces and buildings of various nature and functions.

The first category concerns brownfields which are located in immediate urban centers. The development potential of these sites is mostly very high. Usually they are very attractive 
locations for investors, which enables minimization or complete elimination of expenses for revitalization from public sources. On the other hand, often they are also architectonically valuable buildings or building complexes and locations, in which any interventions are very sensitively perceived by the local residents. One of the most common military brownfields which are found in such locations are historical barracks, which have a very high revitalizing potential at only very minimal interventions of investors into the character of the buildings (e.g. the former armory transformed into the university library of Palacký University in Olomouc).

The farther from the town center and from the principal economic and developmental axes of the municipalities, the lesser the revitalization potential of the brownfields. In these cases, financial intervention of the public sector is very often necessary. In the case of military brownfields, this most often concerns larger complexes of barracks, with buildings of different functions and often also with considerably large open surfaces. These sites can become suitable development locations of municipalities. Due to their usually larger expanse, they can become new multifunctional town districts or can conveniently complete existing urban quarters to make a compact and functioning whole.

Nevertheless, no matter in which part of the municipality the brownfield is located and how the financial involvement of the municipality into its revitalization differs, it is necessary for the local authority not to give up on its public role and not to succumb to the idea that the interest of private capital is always identical with public interest. In these cases, W.F. Lever emphasizes the function of non-governmental organizations, local initiatives and social movements (Lever 2001, p. 279-280). It very often happens, not only in the Czech Republic, that in revitalization, a private concern completely overshadows the public interest. In the selected locations this, however, was not the case. The revitalization of these sites (whether it was successful or not) was carried out with regard for the interests of the sustainable development of the given municipalities, regions or local residents (Kunc et al. 2011).

\section{CAse Studies}

Brownfield revitalization is a financially and organizationally complex process, even in developed economies. Very often, where large post-military sites are concerned, the process of revitalization is divided into several phases, in which use is made of a model of public and private partnership. This is also true of the Czech Republic and demilitarized sites, which cannot do without this cooperation. The following examples show methods and their success in the revitalization of post-military brownfields, in dependence not only on the geographical position, but also on a certain philosophy of approach to the matter.

\section{LOCATIONS 1 AND 2: BARRACKS IN HODONÍN AND UHERSKÉ HRADIŠTE}

Both these Moravian towns lie less than $40 \mathrm{~km}$ apart and from our point of interest have much in common. Until recently, both had barracks of the Armed Forces of the Czech Republic. As part of the reform of the armed forces, these sites were abandoned by the military after 2000 and transferred to the towns at no cost. Although in the case of Hodonín it concerns a total of three sites and in Uherské Hradiště merely one, the main buildings of the 
barracks, which had the largest potential for development, are found near the centers of both towns and also at their edges.

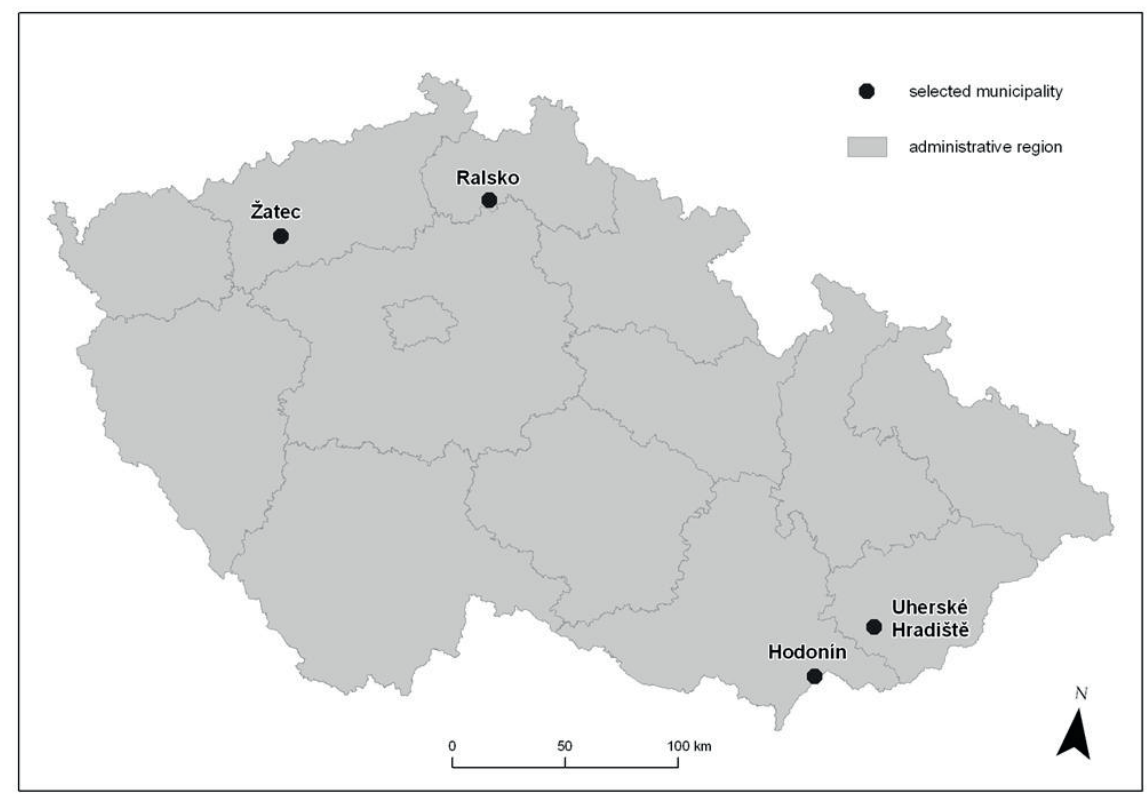

Fig. 2. Localization of case studies within the Czech Republic

As part of the transfer of both sites, the towns drew up land-use plans of these locations, the frameworks of which were divided according to function. While Hodonín took the traditional way of developing mainly small production and a residential function, Uherské Hradiště relied on a combination of the residential and educational function. The very progress of the revitalization differed considerably in the two towns as well. In Hodonín, after initial investment of the town into technical infrastructure, it was decided that most of the buildings should be sold to local businesses, which gradually reconstructed the buildings (also with the aid of EU funding). Thus, except for the infrastructure, only a very small part of the premises remained in possession of the town. By contrast, in Uherské Hradiště the construction of the technical infrastructure was co-financed by a private investor in connection with building a hypermarket. Unlike in Hodonín, the town and municipal organizations kept in their possession most of the buildings on the site. This more markedly opened up possibilities for the town to acquire European grants for the revitalization of the area (3\%:28\% of all the funding for revitalization of the sites) (Špačková 2011, p. 37).

If we focus on the current functional structure of the sites, it largely follows the original objectives of the town councils, and, as shown by the conclusions of a survey held among local residents ${ }^{1}$, most of them are satisfied with the current use of the sites (approximately $88 \%$ in Hodonín and $92 \%$ in Uherské Hradiště). As part of the survey, respondents also marked the best methods of revitalizing the sites. In both cases, most of the respondents

\footnotetext{
${ }^{1}$ Survey conducted in the spring of 2011 on a sample of 150 respondents in each of the towns.
} 
considered revitalization for the purpose of housing to be the best option. In the case of Uherské Hradiště, the reconstruction of part of the site for the purposes of education was evaluated as second best.

Gradually, a number of university departments and other educational institutions settled on the site (especially the Institute of Logistics and Crisis Management, which is now an independent faculty of the Tomas Bata University in Zlín), as a result of which a part of the site has transformed into a small university campus - in the academic year 2011/2012, approximately 990 students are attending the Faculty of Logistics and Crisis Management (personal communication, an employee of the TBU). The importance of such an educational center can be very pronounced for the development of the given town and its broader surroundings. University departments not only contribute to the increase of the overall education of the community, but can also be significant partners in the development of local companies.

In Hodonín, on the premises of the former Great Barracks, another institution of higher education can be found (the European Polytechnic Institute), which is of incomparably less significance. It is a branch of a private college with considerably fewer students. Of much greater importance and developmental potential is the newly established Museum of Oil Mining and Geology, which is situated in the smaller of the barracks-sites, and which, besides having an educational function, mainly has a touristic function. When converting its sites, Hodonín, contrarily to Uherské Hradiště, focused mainly on the development of new business activities in commerce and small-scale production. In both complexes of barracks (the Great and Small Barracks), approximately $75 \%$ of all buildings serve these purposes. It concerns mainly small companies with up to 10 employees (carpenter, glazier, etc.). The largest of them employs a maximum of 40 people.

\section{LOCATION 3: ŽATEC MILITARY AIRPORT}

As an example of a former military site located outside a municipality, we chose the site of the former military airport in Northern Bohemian Žatec (approximately $50 \mathrm{~km} \mathrm{SW}$ of Ústí nad Labem). The site was transformed into an industrial zone of strategic importance, of which there are only five in the Czech Republic. The importance of the industrial zone in Žatec (former military airport) is exceptional not only because of the regional developmental potential, but also from the viewpoint of foreign investments in the Czech Republic.

The acquisition of the former military airport in Žatec was approved by the Council of the Regional Government (Ústí n.L.-region) in April 2002. This act was directly related to the declaration of the site as a strategic industrial zone. Following these events, a period of deterioration of the site, which lasted over nine years, finally came to an end (the troops had left the airport by the end of 1993). According to the plans, especially large foreign companies were to be attracted to the site, and were supposed to become significant employers in the region. The Žatec-region, just as the whole of north-western Bohemia has in fact long been an economically structurally affected region, with high unemployment rates (Žatec $-11,6 \%$, CZ $-8,6 \%$ by the end of 2011) (MPSV 2012).

The first to settle in the new industrial zone were the Japanese companies IPS Alpha and Hitachi, which opened their factories here in late 2007. (Město Žatec 2007). These companies were included in the "Study of the Economic Impacts of the Realization of the Triangle Strategic Industrial Zone"; a document, which was prepared for the Ústí-region at 
the turn of 2007 and 2008. Within it, three versions of utilization of the zone were elaborated: a minimalistic one, counting only on the current two large companies (IPS Alpha and Hitachi); the so-called realistic version, depending on the arrival of other large investors and reaching a total amount of 10000 employees; and the third, so-called maximalist version, allowing for further expansion of the zone and the creation of the so-called Triangle City, where, in theory, up to 20000 employees should work (Zahradník, Jedlička 2008, p. 34) However, reality differs significantly from the Strategies of the anticipated situation. More industrial companies have recently arrived after the two large electronics companies, and are gradually opening production. But even in the most optimistic variant of their development, it cannot be expected that the number of jobs will significantly exceed the level of three thousand (see table 1). The functioning of the companies significantly reflects the economic crisis, which, among other things, has strongly affected the major employer in the zone, the Japanese company IPS Sloha, which in 2009 reduced the number of its employees from the original 1550 to approx. 1150 (Žatecký deník 2009). The problems of this factory culminated with its takeover by Panasonic, which at present employs approx. 620 people as part of its production of LCD-televisions (Panasonic.cz 2011). Currently, completely new investors are arriving in the zone, among others the FVE Triangle company, operating a solar power plant on the site.

Tab. 1. Companies operating in the Triangle industrial zone

\begin{tabular}{|l|l|l|l|}
\hline \multicolumn{1}{|c|}{ Name of company } & \multicolumn{1}{|c|}{ Type of activity } & \multicolumn{1}{c|}{$\begin{array}{c}\text { Number } \\
\text { of employees }\end{array}$} & \multicolumn{1}{c|}{ Notes } \\
\hline Panasonic & LCD TVs & 700 & production \\
\hline Solar Turbines & repair of gas turbines & 450 & in preparation \\
\hline Jonson Controls & $\begin{array}{l}\text { components for car } \\
\text { industry }\end{array}$ & 150 (in future 480) & in preparation \\
\hline Gestamp Louny & $\begin{array}{l}\text { components for car } \\
\text { industry }\end{array}$ & 300 & in preparation \\
\hline Hitachi & $\begin{array}{l}\text { formerly TVs, in the } \\
\text { future car compon. }\end{array}$ & in future 224 & in restructuralisation \\
\hline Panattoni & developer & 450 & $\begin{array}{l}\text { building of 3 or 4 sheds } \\
\text { and their lease }\end{array}$ \\
\hline Hargo & chemical industry & 120 & in preparation \\
\hline FVE Triangle & solar power station & & production \\
\hline
\end{tabular}

Source: Ústecký kraj 2012

Despite initial difficulties, the Triangle industrial zone has a great potential for further development. This is caused mainly by its location towards the capital town of the region and its relative proximity to the border with Germany $(40 \mathrm{~km})$ and the capital city of Prague $(70 \mathrm{~km})$. The site is characterized by quite good transport accessibility. 


\section{LOCATION 4: MILITARY TRAINING AREA RALSKO}

The revitalization of former military training areas, contrary to other military sites, is very different and specific. These sites are up to several times larger and include a high number of military buildings and surfaces of differing types (barracks, garages, storages; or airports, firing ranges, etc.). As regards the settlement structure, these objects are located in differing positions (open or built-up area). Great disadvantages of their further revitalization are environmental burdens, often large in scale.

The former Military Training Area (hereafter MTA) is located on the border of Central and Northern Bohemia and even historically belonged to less developed territories. MTA Ralsko was founded in 1949 as an area for the training of the Czechoslovak Army. After 1968 it was used by the occupying Red Army. The last Soviet soldiers left MTA VVP Ralsko in 1991. The Government of the Czech Republic made the decision to gradually revitalize the area. Government Resolution no. 404/1993 assigned the land-use plans of former MTA Ralsko for processing. On the basis of that, revitalization of the area was to ensue after the necessary clean-up. For the preparation of the revitalization a budgetary organization called PRIVUM was founded in late 1993 (Vočkář 1998, p. 151).

The largest part of former MTA Ralsko (expanse of $250 \mathrm{~km}^{2}$ ) with an area of $170 \mathrm{~km}^{2}$, forms the town of Ralsko². The town was founded by merging formerly independent municipalities and settlements located in the former MTA. When the training area was in use, most of them were evacuated. After the MTA was dissolved, the number of inhabitants of Ralsko gradually increased (index ${ }_{2010 / 1980}=3.8$ ). New residents either moved into reconstructed family housing (original development from the period before the establishment of the MTA) or into revitalized apartment buildings, which were originally inhabited by the families of the Soviet soldiers.

At the end of 1995, basing on identification of the objects in former MTA Ralsko, it was found that there are approx. 1700 apartments and 1200 other buildings (Poštolka 1998, p. 161). By gradual regeneration of the housing dozens of new apartments were created in the town. With the increase of the number of inhabitants, there was not a corresponding improvement in civic amenities or an increase in the number of jobs in the town and its immediate surroundings. Unfortunately, the town thus mainly became a "night shelter" with relatively inexpensive accommodation, of which the residents often commute to work to the approx. $30 \mathrm{~km}$ distant Škoda Auto in Mladá Boleslav.

Business activities and jobs connected with these are not at a sufficient level in Ralsko, even though the number of economic entities in the town saw a more than 2.5-fold increase between 2000 and 2010. However, usually it concerns small tradesmen and small companies (in 2010 83\% natural persons doing business with a trade license or under a different law than the Trade Law) (RES 2010).

This bleak situation is caused by several different factors. Among the most fundamental factors are the yet unfinished privatization of state property, the unsatisfactory technical state of buildings ${ }^{3}$, which could potentially be used for business, and finally errors made especially in the first years of revitalization in the land-use planning in the area.

\footnotetext{
${ }^{2}$ In expanse, it is the second largest city of the Czech Republic, second only to the capital city of Prague.

${ }^{3}$ A large part did not meet Czech state norms and have been deteriorating for over twenty years.
} 
The original concept of the development of the area significantly favored activities in the field of tourism and sports, or small production and business activities, which would not endanger the environment (Vočkár 1998, p. 151). A rethinking of this approach, which refused greater economic activity in the area, did not happen until after 2000. Both the town and the region are currently trying to lure investors, who would not only revive the dilapidating former military sites, but above all would bring a larger number of new jobs to local residents. One example might be the arrival of the largest producer of bathroom furniture in the Czech Republic, the Intedoor company. The arrival of other investors is, however, still hindered, particularly by inadequate technical infrastructure and an unresolved vision for further development of the area.

\section{CONCLUSion}

The departure of the army from an area always brings many negatives on the one hand, but on the other hand a whole range of obvious positives. Due to this process, often relatively large areas, which can significantly contribute to the development of the given municipalities, become available. In line with the concept of sustainable development, housing development is built in an area outside of so-called green locations and integrates the existing functions of municipalities and regions.

Success of the revitalization of the given locations has always depended on a whole variety of hard and soft factors, one of the most important of which seems to be the inventiveness of local political and business representatives. Only they can decide which direction the post-military area will take, whether it will embark on the so-called conservative way, i.e. it will be a solution directed towards a residential function and small-scale production or a combination of both these functions; or whether the given municipality will choose the so-called progressive way, in which the area (if other factors make this possible as well) is used for activities supralocal or even supraregional in nature (educational institutions, industrial zones with important investors, etc.). Both these approaches have been illustrated in the article. It is, however, understandable that within the existing typology of the post-military transformation of an area a whole number of subtypes exist. Therefore, here a relatively broad space opens up for geographical research, which both in Czech and foreign specialized literature is only very poorly represented.

\section{References}

Fňukal M., 2011, Demografické aspekty globalizace, [in:] V. Mezřický (ed.), Perspektivy Globalizace, Portál, Praha, p. 79-109.

Illner M., 2010, Deindustrializace prümyslových měst - projevy, přičiny, důsledky a strategie revitalizace, [in:] L. Hruška-Tvrdý, Industriální město v postindustriálni společnosti, VŠB-TU Ostrava, Ostrava, p. 9-20.

Integrovaný portál MPSV, 2012, Statistiky nezaměstnanosti, portal MPSV, http://portal.mpsv.cz/sz/ stat/nz/mes 
Jackson J., 2003, Brownfields klasifikace a kategorizace - Brownfields ABC, Praha, 14 p.

Jarczewski W., Kuryło M., 2009, Rewitalizacja terenów powojskowych, [in:] W. Jarczewski (ed.), Przestrzenne aspekty rewitalizacji -środmieścia, blokowiska, tereny poprzemystowe, pokolejowe i powojskowe, Institut Rozwoju Miast, Kraków, p. 243-289.

Keller J., 2011, Koncept postindustriální společnosti a jeho slabiny, Sociológia, Vol. 43, No 4, p. 323-337.

Kuda F., Smolová I., 2007, Technické a geografické aspekty integrace neprůmyslových brownfieldi̊ do území, Ostrava, p. 150.

Kunc J., Klusáček P., Martinát S., 2011, Percepce a lokalizace urbánních brownfields: podobnosti a rozdily na př́kladu Brna a Ostravy, Urbanismus a územní rozvoj, Vol. XIV, No 1, p. 13-17.

Lever W.F., 2001, The Post-fordist City, [in:] R. Paddison (ed.), Handbook of Urban Studies, Sage, London, p. 273-283.

Marcuse P., van Kempen M., 2000, Globalizing Cities: A New Spatial Order?, London, p. 336.

Matlovič R., Ira V., Sýkora L., Szczyrba Z., 2001, Procesy transformacyjne struktury przestrzennej miast postkomunistycznych (na przykładzie Pragi, Bratysławy, Ołomuńca oraz Preszowa), [in:] I. Jażdzewska (ed.), Miasto postsocjalistyczne - organizacja przestrzeni miejskiej i jej przemiany (II), XIV Konwersatorium Wiedzy o Mieście, Uniwersytet Łódzki, Łódź, p. 9-21.

Město Žatec, 2007, Slavnostní otevření zóny TRIANGLE, Město Žatec, http://www.mesto-zatec.cz/ videa/31-12-2007/2008-01-05.html

Ministerstvo Financí ČR, 2011, Registr ekonomických subjektů (RES), Praha.

Panasonic, 2011, O společnosti Panasonic Liquid Crystal Display Czech, s.r.o., Panasonic, http:// www.panasonic.cz/html/cs_CZ/O+Panasonicu/Tov\%C3\%A1 rny+v+\%C4\%8CR/PLDCZ+$+\% \mathrm{C} 5 \% \mathrm{BDatec} / \mathrm{O}+\mathrm{Spole} \% \mathrm{C} 4 \% 8$ Dnosti/8087057/index.html

Pecka J., 1996, Odsun sovětských vojsk z Československa 1989-1991, Praha, p. 351.

Šilhánková V. et. al., 2006, Rekonverze vojenských brownfields, Pardubice, p. 218.

Ústecký kraj, 2012, Triangle průmyslová zóna - Investoři v zóně, Ústecký kraj, http://www.kr-ustecky. cz/vismo/dokumenty2.asp?id_org=450018\&id=1660388\&p1=188105

Zahradník P., Jedlička J., 2008, Studie ekonomických dopadi̊ realizace Strategické průmyslové zóny Triangle, Ústí nad Labem, p. 59.

Žatecký deník, 2009, IPS Alpha propouštěla neslušně, zákon ale neporušila, Deník. cz., http://zatecky. denik.cz/zpravy_region/ips_alpha_propousteni_20090330.html

\section{Post-military areas as space for business opportunities and innovation}

One of the characteristic features of the transformation processes taking place in the post-communist countries of Central Europe is the emergence of unused buildings and sites - so-called brownfields. These can be divided into several kinds, according to their original function. One of these is also the so-called military brownfield. Most of such areas were transferred, after the most necessary clean-up, to municipalities, which approached and still approach their further utilization highly individually, in connection with the character of the site as well as that of the municipality itself. Equally individual is the respective successfulness or unsuccessfulness of the revitalization of post-military areas as measured by differing indicators. The functions which revitalized former military areas have acquired are varied. One of the most common is the production function (e.g. industrial zones), residential function (housing zones), production-residential (a mix of production and housing) and production-servicing (a mix of production and services). The following contribution will first analyze demilitarization in the Czech Republic from the point of view of systemic changes in the Czech military doctrine; in the second part 
case studies are introduced, illustrating the transformational changes in selected settlements, caused by the loss of their military function.

Mgr. Jan Hercik

Masaryk University, Brno, Czech Republic

Faculty of Science

Department of Geography

e-mail: hercik@mail.muni.cz

Doc. RNDr. Zdeněk Szczyrba, Ph.D.

Palacký University, Olomouc, Czech Republic

Faculty of Science

Department of Geography

e-mail: zdenek.szczyrba@upol.cz 